\title{
PENINGKATAN PEMAHAMAN SAINS BIOLOGI MELALUI PERMAINAN KARAMBOL
}

\author{
SUBHAN \\ PAUD PPs Univeristas Negeri Jakarta \\ Jln. Rawamangun Muka, Jakarta Timur. Email : $\underline{\text { Subhan.toefl@gmail.com }}$
}

\begin{abstract}
The aim of this study is to describe the process and results of learning through play carom that can improve scientific understanding of biological children in RA BI Salsabila Jakarta Year 2015/2016. The subjects of this study were 22 children. This research method is based on the Research Action Class Action Research model Kemmis and Mc. Taggart which includes four stages: planning, action, observation, and reflection. This study consisted of two cycles, each cycle consisting of 8 times pertemuan.Teknik data analysis used in this research is the analysis of qualitative and quantitative data. Analysis of qualitative data by analyzing data from interviews during the study to the steps of data reduction, data display and data verification. Quantitative data analysis with descriptive statistics to compare the results obtained from preintervention, the first cycle and the second cycle. The results of this study showed an increased understanding of sains biologi children through play carom, evidenced by an average understanding of sains biologi score of 41.59 pre-intervention, then increased in the first cycle of the second cycle of 63.82 and 80.73 .
\end{abstract}

Keywords: understanding, sains biologi, carrom

Abstrak: tujuan penelitian ini yaitu untuk menggambarkan proses dan hasil belajar melalui permainan karambol yang dapat meningkatkan pemahaman sains biologi anak di RA B1 Salsabila Jakarta Timur Tahun 2015/2016. Subyek penelitian ini yaitu 22 orang anak. Metode penelitian ini adalah Penelitian Tindakan yang mengacu pada model Penelitian Tindakan Kelas Kemmis dan Mc. Taggart yang meliputi empat tahap: perencanaan, tindakan, observasi, dan refleksi. Penelitian ini terdiri dari dua siklus, setiap siklus terdiri dari 8 kali pertemuan.Teknik analisis data yang digunakan dalam penelitian ini adalah analisis data kualitatif dan kuantitatif. Analisis data kualitatif dengan menganalisis data dari wawancara selama penelitian untuk langkah-langkah reduksi data, display data dan verifikasi data. analisis data kuantitatif dengan statistik deskriptif yang membandingkan hasil yang diperoleh dari pre-intervensi, siklus I dan siklus II. Hasil penelitian ini menunjukkan adanya peningkatan pemahaman sains biologi anak melalui permainan karambol, dibuktikan dengan rata-rata pemahaman skor sains biologi praintervensi sebesar 41,59, kemudian meningkat pada siklus I sebesar 63,82 dan siklus kedua sebesar 80,73.

Kata Kunci: pemahaman, sains biologi, permainan karambol 
Pembelajaran sains bagi anak usia dini ditujukan agar anak memiliki kemampuan memecahkan masalah, memiliki sikap ilmiah, dan mengasah kepekaan panca indera dalam bereksplorasi untuk memahami lingkungan sekitar. Kemampuan tersebut dapat terwujud, secara ideal hanya melalui pelaksanaan pembelajaran sains yang bersandar pada tiga dimensi utama yaitu sains sebagai proses, sains sebagai produk dan sains sebagai sikap. Sains sebagai produk, sikap, dan proses yang dibelajarkan untuk anak usia dini, seyogyanya ditempuh melalui kontenkonten sains permulaan yang sesuai dengan usia dan tingkat perkembangan anak.

Sains biologi atau dikenal juga dengan istilah life science merupakan bagian dari sains permulaan untuk anak usia dini. Dalam STTPA (Standar Tingkat Pencapaian Perkembangan Anak), sains biologi merupakan salah satu muatan belajar yang diturunkan dan disesuaikan dengan aspek perkembangan kognitif anak usia dini (0-6) tahun. Sains biologi meliputi fakta, konsep, teori, prinsip dan hukum yang berkaitan dengan tumbuh-tumbuhan, binatang atau hewan, hubungan antara tumbuhan dan hewan, serta aspekaspek kehidupan dengan lingkungannya.

Konten-konten sains biologi melatih anak menggunakan panca inderanya; melihat, meraba, membau, merasakan dan mendengar. Semakin banyak keterlibatan indera dalam belajar, anak semakin memahami apa yang dipelajari. Anak memperoleh pengetahuan baru hasil penginderaanya dengan berbagai benda yang ada disekitarnya. Terlebih ketika anak bermain bersama dengan temannya, anak akan terlatih untuk mampu bekerjasama dan secara impulsif memperoleh bimbingan (scafolding) dari teman yang tingkatan perkambangannya lebih tinggi. Salah satu permainan yang dapat menjadi media bagi anak dalam mewujudkan hal tersebut adalah permainan karambol.

Permainan karambol merupakan jenis permainan papan yang dapat dimainkan secara berkelompok dan memiliki aturan yang dipatuhi secara bersama. Secara teoritis, hal tersebut sesuai dengan 
karaktersitik perkembangan kognitif dan sosial anak usia 5-6 tahun. Karambol yang merupakan keluarga dari permainan dengan kelompok (group play) dan permainan dengan aturan (games with rules), dapat meransang pemahaman sains biologi anak melalui modifikasi materi secara fiskal yang diintegrasikan ke dalam komponen permainan karambol.

$$
\text { Seperti menstimulus }
$$

kemampuan klasifikasi, dapat dilakukan melalui modifikasi kepingan karambol dengan gambargambar hewan berkarakter tertentu. Kepingan tersebut dimasukkan ke dalam pocket karambol yang sesuai dengan karaktersitik yang ada pada disk. Melalui cara ini, anak secara tidak sadar akan memiliki pemahaman tentang penggolongan hewan berdasarkan karaktersitiknya. Begitu juga bagaimana meransang dimensidimensi pemahaman sains biologi lainnya seperti memberi contoh, menjelaskan, memprediksi sampai kepada aspek menyimpulkan.

Terdapat banyak jenis permainan yang dapat meningkatkan pemahaman sains anak seperti permainan medan magnet, sulap bunga, telur ajaib, kapur barus loncat, serta yang paling populer digunakan adalah percobaan gunung meletus. Jenis-jenis permainan ini merupakan permainan eksperimen yang tidak terlalu memberikan ruang gerak bagi anak untuk menjadi pelaku utama dalam permainan tersebut karena memang pelaksanaannya membutuhkan skenario matang agar alat dan bahan yang digunakan tidak mebahayakan anak. Untuk itu, permainan sains semacam ini lebih banyak digunakan guru dalam bentuk demonstrasi, dimana anak hanya bisa menyaksikan dan bukan mengalami sendiri.

Lain halnya dengan permainan karambol. Dimana anak-anak akan dilibatkan secara penuh dalam menjalankan permainan. Unsur kompetisi dan kerjasama tim yang ada, membuat anak saling membimbing dan mengarahkan satu sama lain. Dimana menurut teori scalfolding, anak pada situasi sosial yang sama namun memiliki tingkat kematangan dan usia yang berbeda akan saling memberikan membimbingan. Dengan demikian, konten-konten sains biologi dalam 
permainan karambol akan lebih mudah dicerna dan dipahami anak karena anak akan saling berbagi dan memberitahu materi sains biologi satu sama lain untuk memenangkan permainan.

Disamping itu, sejumlah permainan untuk meningkatkan pemahaman sains sebagaimana dipaparkan di atas, merupakan permainan yang tidak mudah untuk dimodifikasi dan diintegrasikan dengan konten-konten sains biologi. Sementara, karambol dengan keping, lubang dan papan yang sangat fleksibel dapat dimodifikasi menjadi model aquarium alam mini bagi anak, dimana anak dapat mengenal dunia hewan dan binatang hanya dengan melihat gambar yang dapat digerakkan dan dimainkan dengan lebih menarik. Hal ini dapat menjadi alternatif orang tua dalam mengkondisikan anak menjadi lebih aman daripada membawanya ke kebun binatang atau alam liar yang membutuhkan tingkat pengamanan yang ketat dan biaya yang relatif mahal.

Jenis permainan yang banyak melibatkan peran dan pengamatan panca indera anak seperti permainan karambol, menurut kajian empirik telah terbukti berkontribusi positif terhadap hasil pembelajaran sains biologi pada anak usia dini. Sesuai dengan apa yang dilaporkan Naswastu Anggie Ratsih dalam penelitiannya yang berjudul peningkatan kemampuan dasar sains melalui bermain berbasis inquiri bahwa hasil tes menunjukkan bahwa melalui bermain berbasis inquir kemampuan dasar sains dapat meningkat $85 \%$ dan hasil observasi menunjukkan $80 \%$ siswa mendapatkan penilaian baik. Sementara itu, Sunarti dalam penelitiannya yang berjudul Upaya Mengembangkan Kemampuan Sains Melalui Permainan Eksploratif mengungkap bahwa Pembelajaran dengan permainan eksploratif ternyata menghasilkan $45 \%$ anak yang mampu mengenal pengenalan sains dengan baik.

Kontras dengan paparan di atas, realitas pembelajaran sains biologi yang terjadi di RA B Salsabila Jakarta Timur justru masih jauh dari harapan. Berdasarkan hasil observasi awal yang peneliti lakukan terhadap 22 orang anak RA B1, pemahaman 
konten sains biologi dari 5 indikator awal yang peneliti amati, terdapat 3 indikator yang belum dikuasai dengan baik oleh 15 orang anak. Indikator tersebut antaralain karaktersitik hewan dan tumbuhan tidak dipahami oleh 12 orang anak, habitat hewan dan tumbuhan sejumlah 15 anak, serta pengenalan tubuh manusia sejumlah 14 orang anak. Sebaran capaian indikator yang dimaksud meliputi: pemahaman dengan kategori Belum Muncul (BM)berjumlah 15 orang anak, Mulai Berkembang (MB) sebanyak 4 orang anak, Berkembang Sesuai Harapan (BSH) dan Berkembang Sangat Baik (BSB) masing-masing berjumlah 2 dan 1 orang anak.

Pada materi karakterstik hewan dan tumbuhan, rata-rata anak belum mampu memberikan contoh secara kompleks jenis hewan pemakan daging dan tumbuhan, cara perkembang biakannya, serta anak masih kesulitan dalam memahami tumbuhan dan hewan berdasarkan ciri-ciri tertentu. Selanjutnya, pada materi habitat hewan dan tumbuhan, meskipun beberapa anak telah mampu menyebutkan hewan atau tumbuhan sesuai dengan habitatnya, tetapi jenis hewan yang diketahui masih sangat sedikit, dan belum mampu membandingkan bentuk tubuh hewan secara spesifik yang hidup dengan habitat yang berbeda. Kemudian, pada materi pengenalan anggota tubuh, masih banyak anak yang belum mampu memetakkan mana anggota tubuh yang termasuk alat indera dan bukan alat indera dan mengelompokkan alat indera berdasarkan letak dan fungsinya.

Rendahnya pencapaian anak dalam pembelajaran sains biologi sebagaimana dipaparkan di atas, salah satunya disebabkan oleh intensitas penggunaan alat bermain sains biologi yang masih sangat terbatas. Beberapa alat bermain yang tersedia justru lebih mengarah kepada alat bermain physical science (fisika) dan earth science (geografi). Alat bermain phisical science misalnya, terdapat balok, ayunan, jungkat-jungkit, bola dunia dan lain sebagainya. Begitu juga halnya dengan alat bermain earth science, terdapat berbagai alat bermain seperti bola dunia, peta, kompas, dan lain sebagainya. Sementara, alat bermain sains biologi 
terbatas baik secara jumlah atapun variasi; terlihat RA Salsabila hanya sebatas torso dan imitasi ikan.

Disamping itu, aktiftasaktifitas sains dalam kelas hanya sebatas hafalan dan pengetahuan, tidak mengarah kepada pemerolehan keterampilan ataupun pembentukan sikap. Pembelajaran sains yang terjadi masih bersifat konvensional; dimana guru menerangkan dan anak mendengarkan. Pembelajaran sains yang seharusnya membawa anak kedalam pengalaman nyata melalui kegiatan eksplorasi dan observasi sederhana, terbatas hanya pada materi yang disampaikan oleh guru. Guru masih banyak mengandalkan sumber belajar atau materi dari buku pelajaran sebagai pengantar materi sains, padahal disatu sisi anak harus menggali pengetahunnya melalui pengalamannya sendiri. Hal ini menyebabkan anak kurang terlibat dalam pembelajaran. Banyak anak yang terlihat mengobrol dan asyik sendiri bersama temannya, mengantuk, membuat kegaduhan, dan pada akhirnya menimbulkan kebosanan dan kejenuhan.
Proporsi belajar sains yang diajarkan guru juga belum seimbang, pembelajaran lebih banyak terfokus pada pysical science (ilmu fisika) dan earth science (ilmu bumi) sementara guru mengabaikan konten sains biologi atau life science. Konten sains biologi masih jarang tersentuh, anak sesekali hanya dibimbing untuk mengenal dan mengamati gejalagejala fisik seperti konsep tenggelam terapung, gunung meletus, tarik dorong dan lain-lain. Sebagaimana penjabaran sebelumnya, hal ini pun didemonstrasikan oleh guru, bukan anak yang melakukan dan mengalaminya secara langsung. Sementara konsep-konsep sains biologi seperti hewan dan tumbuhan, lingkungan, dan konsep diri (body) anak merupakan konsep sains paling dekat dengan diri anak belum mendapatkan perhatian maksimal. Padahal, jika dikaji lebih jauh, kontenkonten yang ada dalam sains biologi merupakan konten yang lebih dekat dengan kehidupan anak bila dibandingkan dengan konten-konten phisicals cience dan earth science. Hal ini juga sesuai dengan prinsip pengembangan materi untuk 
pembelajaran anak usia dini yaitu dekat, sederhana, dan mudah dipahami oleh anak.

Berdasarkan berbagai paparan di atas, peneliti tertarik untuk melakukan penelitian di RA B Salsabila Jakarta Timur dengan judul "Peningkatan Pemahaman Sains Biologi Melalui Permainan Karambol (Penelitian Tindakan di RA B1 Salsabila Jakarta Timur Tahun 2015/2016)."

\section{Pemahaman Sains Biologi}

Menurut Ali Nugraha (2005:94) sains biologi atau lebih dikenal dengan ilmu hayati merupakan bidang kajian sains yang meliputi botani, zoology dan ekologi. Tiga bidang kajian sains biologi ini adalah tentang mahluk hidup dengan segala karakteristiknya.

Acramento (2012:57) dalam Jurnal California Preschool Learning Foundation memperjelas pandangan bahwa konsep inti sains biologi adalah properti dan karakteristik mahluk hidup serta bagaimana mereka tumbuh dan berkembang. Konten yang menjadi objek pengamatan siswa terkait dengan karakteristik umum hewan dan tumbuhan menyangkut bagian tubuh, tingkah laku, tempat hidup dan bagaimana tumbuh kembang hewan dan tumbuhan tersebut secara sederhana. Ingrid dan Karen (2006:100) menjelaskan bahwa konten sains biologi untuk anak usia dini meliputi karakteristik fisik mahluk hidup, kebutuhan dasar menyangkut perilaku sederhana dari mahluk hidup, hubungan antara makhluk hidup dan lingkungannya. Sejalan dengan penjelasan diatas, Karen dan Sharon (2003:39) menjelaskan bahwa sains biologi dalam pendidikan anak usia dini terkait dengan bagaimana anak mengobservasi hewan dan tumbuhan, bagaimana anak dapat berfikir tentang mahluk hidup, bagaimana kehidupan mahluk hidup dan bagaimana mahluk hidup dapat tumbuh dan berkembang. Rossalind dan Karen menjabarkan lebih terperinci mengenai konsep dasar untuk memahami sains biologi adalah dengan memahami materi tentang tumbuhan, hewan dan mahluk hidup.

Berdasarkan uraian beberapa ahli di atas dapat disimpulkan bahwa kemampuan pemahaman sains biologi pada anak usia dini yaitu salah satu cabang ilmu sains dengan objek kajian 
meliputi: karakteristik hewan dan tumbuhan, habitat hewan dan tumbuhan serta pengenalan tubuh manusia.

\section{Permainan Karambol}

Piaget (Yuliani, 2009: 114) mengatakan bermain merupakan suatu kegiatan yang dilakukan berulangulang dan menimbulkan kesenangan/kepuasan bagi diri seseorang. Lebih lanjut, Piaget juga mengartikan bermain sebagai bentuk praktik konsolidasi pemerolehan mental skill; bermain memfasilitasi translasi pengalaman ke dalam makna internal (Sandra,1993:4) Sedangkan Parten memandang kegiatan bermain sebagai sarana sosialisasi. Lebih lanjut, Docket berpandangan bahwa bermain merupakan kebutuhan bagi anak karena melalui bermain anak akan memperoleh pengetahuan yang dapat mengembangkan kemampuan dirinya.

$$
\text { Berdasarkan pandangan }
$$

tersebut, bermain dapat dipandang sebagai kegiatan yang dapat membawa perasaan senang dan bahagia. Melalui bermain, seorang anak akan memperoleh pengalaman dan berinteraksi dengan lingkungannya secara alami tanpa paksaan. Untuk itu, permainan bagi anak merupakan sarana untuk bersosialisasi, merekonstruksi pengetahuan serta pengalaman menjadi sebuah kemampuan dan potensi diri.

Menurut Moeslichatoen (2004:24), bermain merupakan kegiatan yang memberi kepuasan bagi diri sendiri. Melalui bermain, anak memperoleh pembatasan dan memahami kehidupan. Bermain merupakan kegiatan yang memberikan kesenangan dan dilaksanakan untuk kegiatan itu sendiri, yang lebih ditekankan adalah caranya dari pada hasil dari kegiatan tersebut. Senada dengan itu, Dearden menjelaskan bahwa bermain adalah kegiatan yang nonserius dan segalanya ada dalam kegiatan itu sendiri yang dapat memberi kepuasan bagi anak.

Selanjutnya, dalam sumber yang berbeda, Erikson mengatakan "Child's play is the infantile form of the human ability to deal with experience by creating model situations and to master reality by experimenting and planning" (Sandra, 
1993:4). Pandangan ini meyakini bahwa bermain adalah bentuk kemampuan anak untuk menghadapi pengalaman dengan menciptakan model untuk menguasai realitas melalui eksperimen. Dapat dikatakan, permainan merupakan simulasi realitas untuk melatih pengalaman dan keterlibatan anak dalam dunia yang sesungguhnya.

Sementara itu, Judith Van Hoorn, dkk (2003:22), memberikan pandangan yang sedikit berbeda yaitu "play is the source of laughter and humor, of inventiveness and beauty; it allows us to entertain possibilities and to envision the future; it help us to persevere in our efforts and to explore the full range of our emotions." Pandangan ini menjelaskan bahwa bermain adalah sumber tawa dan humor, melalui bermain, memungkinkan anak membayangkan masa depan; membantu anak untuk terus tekun dalam usahanya serta untuk mengeksplorasi dan mengontrol berbagai emosi yang timbul.

$$
\text { Berdasarkan berbagai }
$$

pandangan di atas, dapat disimpulkan bahwa bermain adalah kegiatan yang dilakukan secara sukarela; berlandaskan perasaan senang dan gembira; secara tidak sadar akan dapat menciptakan pengalaman bahkan pengetahuan bagi anak melalui eksplorasi, sosialiasi, dan juga interaksi yang terjadi dalam aktifitas bermain tersebut.

\section{Metode Penelitian}

Metode penelitian yang digunakan adalah penelitian tindakan (action research). Penelitian tindakan ini menggunakan desain model Kemmis \& Mc Taggart yang meliputi empat tahap yaitu perencanaan (plan), tindakan (act), pengamatan (observe), refleksi (reflect) . pada model kemmis \& Mc Taggart tindakan (act) dan pengamatan (observe)dijadikan sebagai satu kesatuan karena kedua komponen tersebut merupakan dua kegiatan yang tidak bisa dipisahkan.

Penelitian ini dikatakan berhasil apabila minimal $71 \%$ dari jumlah anak yaitu 17 dari 22 anak mencapai TCP Minimal yang ditentukan bersama dengan kolabolator. Pada penelitian ini TCP Minimal sebesar $75 \%$ dari TCP Maksimal. 
TCP Maksimal $=\sum$ Butir xKatagori

$$
\begin{aligned}
& =24 \times 4 \\
& =96
\end{aligned}
$$

TCP Minimal $=\frac{75}{100} \times 96$

$$
=72
$$

Teknik pengumpulan data yang digunakan dalam penelitian ini adalah catatan lapangan, dokumentasi, wawancara, dan observasi. Catatan lapangan terdiri dari apa yang dilihat, didengar, dan dipikirkan oleh peneliti dalam rangka mengumpulkan data. Dokumentasi dalam penelitian ini yaitu mengumpulkan informasi tentang laporan pemahaman sains biologimelalui kegiatan bermain karambolberupa foto dan video. Wawancara dalam penelitian ini dilakukan kepada guru RA B1 Salsabila Jakarta Timur. Observasi dilakukan dengan instrumen pemantau tindakan guru dan instrumen yang digunakan dalam penilaian peningkatan pemahaman sains biologi anak RA B1 Salsabila Jakarta Timur setelah tindakan.

$$
\text { Kisi-kisi instrumen }
$$

dikembangkan melalui definisi konseptual dan operasional yang menjelaskan bahwa pemahaman sains biologi adalah skor yang menggambarkan tingkat kemampuan seorang anak dalam mengklasifikasikan, mencontohkan, menyimpulkan, membandingkan, serta menjelaskan suatu fakta, konsep, atau prinsip yang terdapat dalam materi karakteristik hewan dan tumbuhan, habitat hewan dan tumbuhan serta pengenalan tubuh manusia yang diperolehnya melalui komunikasi dengan orang lain baik secara tulisan, verbal maupun piktorial. Pengambilan data dalam penelitian ini melalui teknik observasi dengan cara memberikan skor pada lembar observasi pemahaman sains biologi yaitu tingkatan Belum Berkembang (BB) diberikan skor 1 , Mulai Berkembang (MB) skor 2, Berkemang Sesuai Harapan (BSH) skor 3,dan Berkembang Sangat Baik (BSB) skor 4,dimana skor ini menjelaskan tingkatan pemahaman sains biologi yang dicapai oleh anak RA B Salsabila Jakarta Timur.

Analisis data yang digunakan adalah analisis data kualitatif dan analisis data kuantitatif. Analisis data kualitatif dengan cara menganalisis data dari hasil catatan lapangan dan wawancara selama penelitian dengan 
langkah-langkah dengan statistik deskiptif yaitu membandingkan hasil yang diperoleh dari pra-intervensi, siklus dan siklus kedua.

\section{Hasil dan Pembahasan}

Hasil penelitian menunjukkan bahwa pemahaman sains biologi anak RA B1 Salsabila Jakarta Timur sudah mulai meningkat dari pra-intervensi sampai siklus II.

\section{Pra-intervensi}

Asesmen awal ini dilakukan untuk mengetahui kondisi awal pemahaman sains biologi di RA B1 Salsabila Jakarta Timur. Adapun hasil asesmen awal untuk pemahaman sains biologi, sebagai berikut:

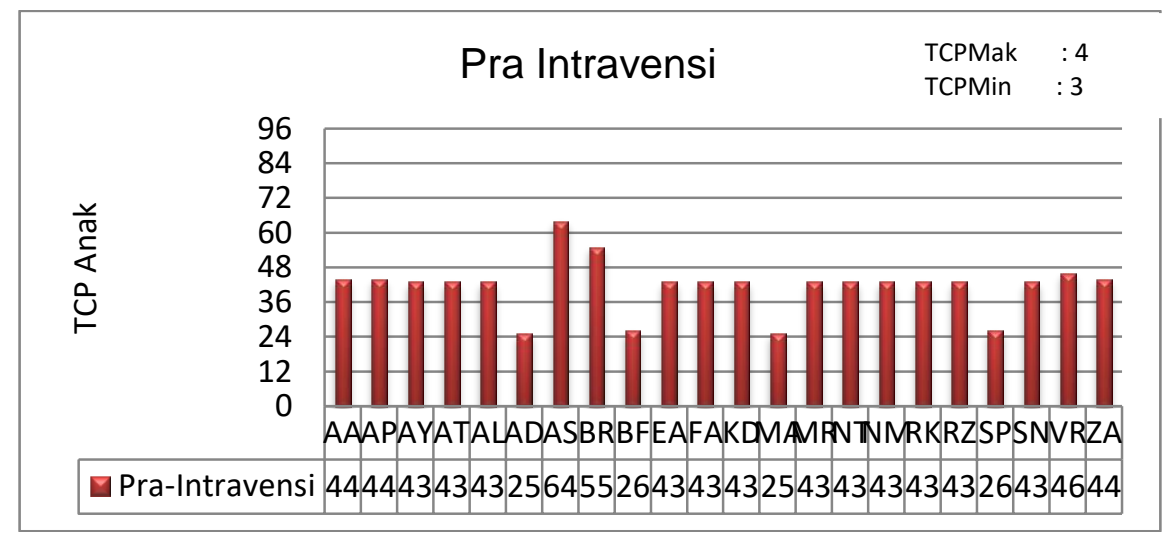

\section{Gambar 1. GrafikPra-intervensiPemahaman Sains Biologi Anak RA BISalsabila Jakarta Timur Tahun 2015/2016}

Grafik di atas menggambarkan bahwa rata-rata TCP pemahaman sains biologi pada anak RA B1 Salsabila pada pra-intervensi berada pada katagori belum berkembang, yaitu dengan TCP Anak ratarata kelas 41,59 Dari 22 anak, 2 anak AD dan MA mendapatkan TCP Anak terendah yaitu 25 dan AS mendapatkan TCP Anak tertinggi sebesar 64 .

\section{Siklus I}

Observasi pada siklus I dilakukan untuk mengetahui skor yang diperoleh anak setelah pemberian tindakan melalui permainan karambol dalam meningkatkan pemahaman sains biologi. Adapun data observasi pada siklus I adalah 
Volume 10 Edisi 1, April 2016

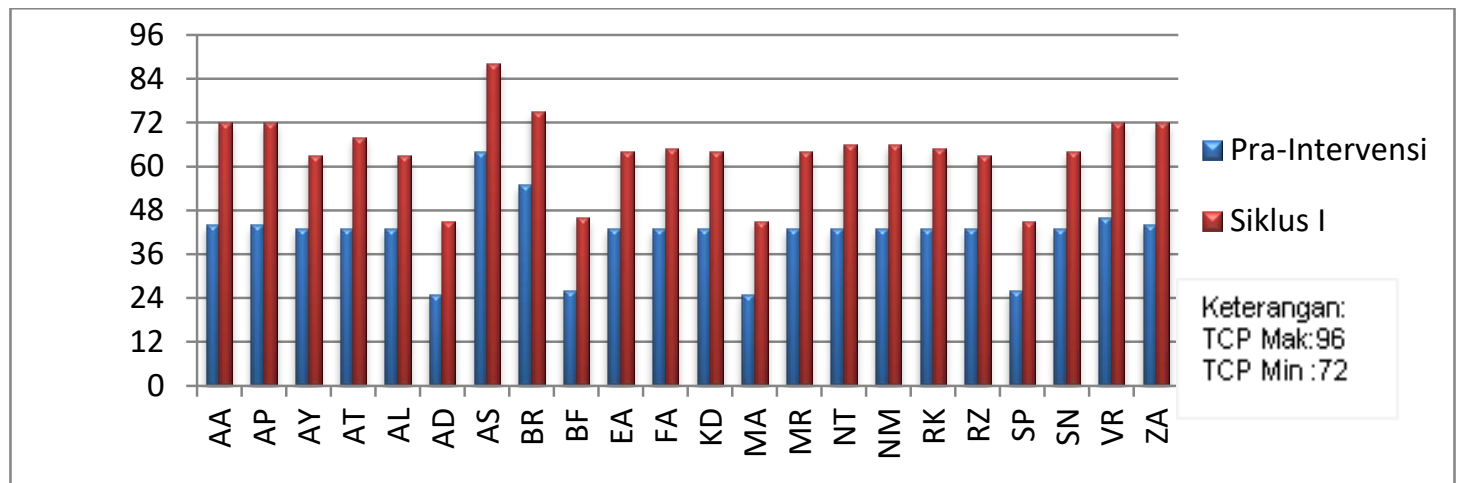

Gambar 2 Grafik Peningkatan Pemahaman Sains Biologi Anak pada Pra-Intervensi dan Siklus I

Data pada grafik menunjukkan peningkatan pemahaman sains biologi anak dari sebelum mendapat kegiatan bermain karambolsampai pada siklus I yang telah mendapatkan kegiatan bermain karambol. Pada grafik tersebut terlihat peningkatan pemahaman sains biologi anak RA B1 Salsabila Jakarta Timur yang berjumlah 22 orang dapat terlihat pada rata-rata praintervensi yang mencapai TCP Anak 41,59 dan pada siklus I menjadi 63,82. Disini terlihat belum mencapai batas ketentuan minimal.

Oleh karena itu peneliti dan kolabolator menyepakati untuk melanjutkan ke siklus II. Hal ini dilakukan atas kesepakatan antara peneliti dan kolabolator dengan pertimbangan agar pemahaman sains biologi anak meningkat sesuai dengan harapan yang telah ditentukan dengan memperbaiki kekurangan pada siklus I agar lebih maksimal pada siklus II.

\section{Siklus II}

Observasi pada siklus II dilakukan mengetahui skor yang diperoleh anak setelah pemberian tindakan permainan karambol dalam meningkatkan pemahaman sains biologi. Adapun data observasi pada siklus II adalah 


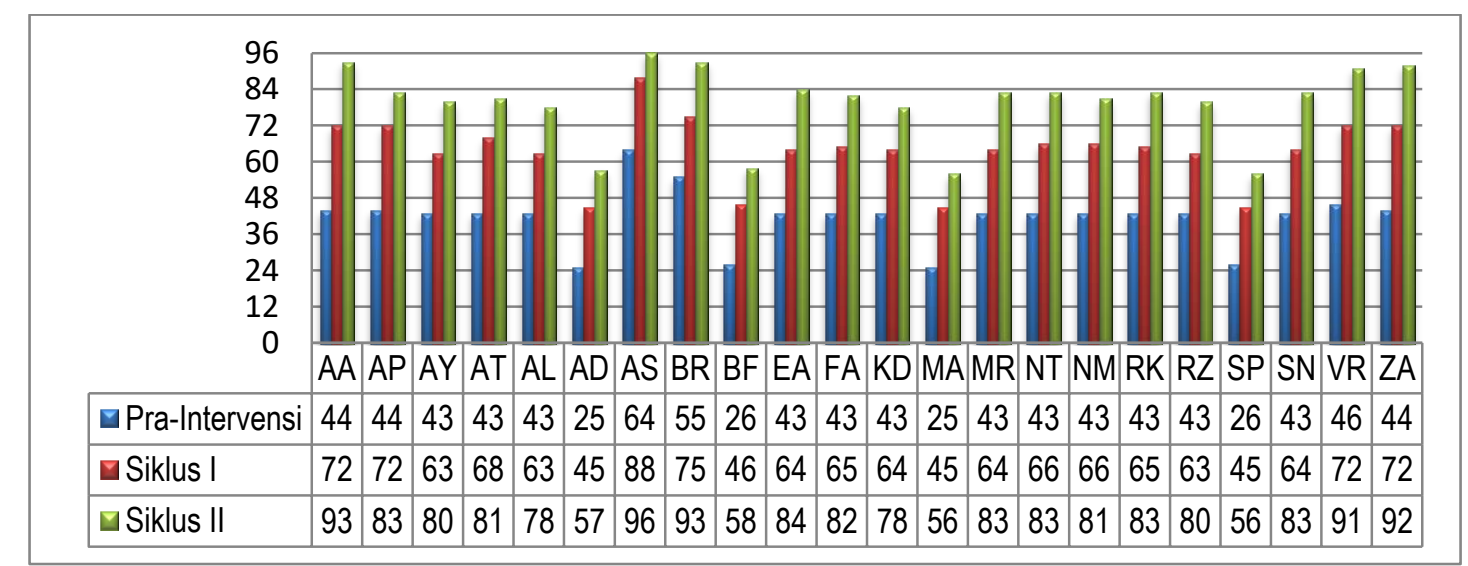

Gambar 3 Grafik Pemahaman Sains Biologi Anak Pada Pra Intervensi, Siklus I, dan Siklus II Anak RA BI Salsabila Jakarta Timur Tahun 2015/2016

Data pada tabel dan grafik menunjukkan peningkatan pemahaman life scince anak RA B1 Salsabila Jakarta Timur yang berjumlah 22 orang dapat dilihat pada rata-rata pra-intervensi yang mencapai TCP Anak 41,59 mengalami peningkatan TCP Anak pada siklus I sebesar 22,23 menjadi 63,82 selanjutnya dari siklus I ke siklus II pemahaman sains biologi anak mengalami peningkatan TCP Anak 16,91 menjadi 80,73 disini terlihat sudah

mencapai batas ketentuan minimal. Dari hasil pencapaian tersebut, maka peneliti dan kolabolator menyepakati bahwa tindakan sampai pada siklus II.

\section{Pembahasan}

Berdasarkan pemerolehan data secara kualitatif dan kuantitatif. Penelitian ini telah membuktikan bahwa permainan karambol dapat meningkatkan pemahaman sains biologi anak RA BI Salsabila Jakarta Timur. Hasil ini dibuktikan dari pemberian tindakan yang diberikan pada siklus I dan siklus II. Pada siklus I dan siklus II anak melakukan permainan karambol yang terintegrasi dengan konten sains biologi yang dilakukan secara berkelompok dengan aturan tertentu.

Hasil penelitian menunjukkan bahwa pada akhir siklus I dan siklus II, peneliti dan kolabolator melakukan perhitungan terhadap hasil observasi pemahaman sains biologi anak. Berdasarkan data hasil pengamatan tindakan yang telah dilakukan terhadap 22 responden pada akhir siklus I, dapat diketahui bahwa pemahaman sains biologi anak mengalami peningkatan sebesar 22,23 pada pra-intervensi memperoleh rata-rata kelas 41,59 dan pada siklus I menjadi 63,82. Pada siklus II pemahaman sains biologi anak mengalami peningkatan sebesar 16,91 dimana pada siklus II anak mendapat rata-rata TCP Anak 80,73. Hal ini membuktikan bahwa permainan karambol dapat meningkatkan pemahaman sains biologi anak. 
Volume 10 Edisi 1, April 2016

Pemahaman sains biologi anak yang ditunjukkan oleh anak selama diberikan tindakan penelitian dilihat dari berbagai inidkator diantaranya indikator membandingkan ciri-ciri morfologis beberapa jenis tumbuhan dengan kriteria tertentu, menjelaskan keadaan lingkungan tempat tinggal hewan, menjelaskan keadaan lingkungan tempat hidup tumbuhan, serta mengklasifikasikan fungsi anggota tubuh manusia berdasarkan kriteria alat indera dan bukan alat indera. Pemerolehan pemahaman sains biologi ini diamati dalam berbagai aktivitas yang dilakukan anak melalui permainan karambol. Permainan karambol memberikan anak tantangan tersendiri untuk mememahami konten sains biologi yang terintegrasi pada seluruh komponen permainan, sehingga anak belajar hanya seperti melakukan permainan biasa yang mereka gemari dan senang untuk dilakukan.

Kegiatan pembelajaran yang digunakan untuk meningkatkan pemahaman sains biologi anak dalam penelitian ini adalah permainan karambol. Permainan karambol ini mengembangkan pemahaman sains biologi anak secara optimal. Pemahaman sains biologi anak usia 5-6 tahun yang muncul dan berkembang dalam penelitian ini meliputi (1) Memberikan contoh hewan berdasarkan ciri-ciri morfologis tertentu, (2) Menjelaskan ciriciri morfologis hewan tertentu, (3) Mengklasifikasi jenis hewan berdasarkan ciri-ciri morfologis tertentu,

Membandingkan ciri-ciri morfologis beberapa hewan dengan kriteria tertentu, (5) Memberikan contoh tumbuhan berdasarkan ciri-ciri morfologis tertentu,

Menjelaskanciri-ciri morfologis tumbuhan tertentu, (7) Mengklasifikasi jenis tumbuhan berdasarkan ciri-ciri morfologis tertentu, (8) Membandingkan ciri-ciri morfologis beberapa jenis tumbuhan dengan kriteria tertentu, (9) Memberikan contoh hewan berdasarkan lingkungan atau tempat tinggal tertentu, (10) Menjelaskan keadaan lingkungan tempat tinggal hewan, (11) Mengklasifikasi hewan berdasarkan tempat tinggalnya, (12) Membandingkan ciri-ciri morfologis hewan yang hidup dan tinggal pada lingkungan atau tempat yang berbeda, (13) Memberikan contoh tumbuhan dengan lingkungan atau tempat tinggal tertentu,

Mengklasifikasitumbuhan berdasarkan tempat tinggalnya, (15) Menjelaskan keadaan lingkungan tempat hidup tumbuhan, (16) Membandingkan ciri-ciri morfologis tumbuhan yang hidup dan tinggal pada tempat yang berbeda, (17) Memberikan contoh anggota tubuh manusia, (18) Mengklasifikasi anggota tubuh manusia, (19) Menjelaskan bagianbagian anggota tubuh manusia, (20) Membandingkan bagian-bagian anggota tubuh manusia, (21) Memberikan contoh fungsi anggota tubuh manusia, 
Peningkatan Pemahaman ...

Subhan

Mengklasifikasikan fungsi anggota tubuh manusia berdasarkan kriteria alat indera dan bukan alat indera, (23) Menjelaskan fungsi anggota tubuh manusia,

Membandingkan fungsi bagian-bagian anggota tubuh manusia yang termasuk sebagai alat indera. Kemampuan ini terlihat saat penelitian berlangsung saat dilaksanakannya permainan karambol.

Adapun yang dibahas dalam penelitian ini hanyalah indikator bermasalah yaitu membandingkan ciri-ciri morfologis beberapa jenis tumbuhan dengan kriteria tertentu, menjelaskan keadaan lingkungan tempat tinggal hewan, menjelaskan keadaan lingkungan tempat hidup tumbuhan, serta mengklasifikasikan fungsi anggota tubuh manusia berdasarkan kriteria alat indera dan bukan alat indera. Dimana 20 indikator lainnya seperti yang telah diuraiakan di atas, tidak termasuk indikator bermasalah karena sebagian besar anak tidak merasa kesulitan dalam memahami meskipun beberapa anak masih terlihat perlu pendalaman.

Berdasarkan data kualitatif dalam penelitian ini pemahaman anak dalam indikator membandingkan ciri-ciri morfologis beberapa jenis tumbuhan dengan kriteria tertentu, lebih terlihat dalam melakukan permainan karambol. Pada dasarnya, anak mempunyai rasa ingin tahu yang tinggi. Ketika anak melihat konten sains biologi ada pada sebuah permainan yang ia sukai, maka anak selalu ingin tau bagaimana konten-konten tersebut dapat dimainkan. Dengan kemasan permainan yang menarik, membuat anak lebih antusias untuk mengikuti permainan. Ketika anak sudah tertarik, maka anak dengan sendirinya akan memahami lebih jauh konten sains biologi yang ada pada permainan tersebut karena sukses tidaknya dalam permainan ini ditentukan sejauhmana anak memahami konten sains biologi yang terintegrasi pada komponen permainan. Pada akhirnya, saat permainan berlangsung, anak mampu membandingkan ciri-ciri morfologis beberapa jenis tumbuhan dengan kriteria tertentu.

Pada indikator menjelaskan keadaan lingkungan tempat tinggal hewan, pemahaman anak ditunjukkan ketika guru melakukan review diakhir kegiatan, guru berkepinganusi bersama membahas semua kegiatan yang telah dilakukan. Anak mampu menceritakan lingkungan tempat tinggal hewan kepada guru. Guru memancing pemahaman anak dengan mengulas kembali proses demi proses yang dilakukan dalam permainan, dari hal tersebut anak secara spontan menceritakan bagaimana keadaan lingkungan tempat hidup hewan berdasarkan pengalaman mereka secara sederhana. 
Volume 10 Edisi 1, April 2016

Begitu juga pada indikator menjelaskan keadaan lingkungan tempat tinggal tumbuhan. Sama dengan indikator di atas, pemahaman anak dapat dilihat ketika guru melakukan review yaitu berkepinganusi dengan anak tentang konten sains biologi yang terintegrasi dengan permainan karambol. Disamping itu, teramati juga ketika anak berkepinganusi dengan teman satu timnya ketika sedang melakukan permainan karambol. Sebelum memasuki kepingan, anak harus meminta pendapat temannya, bertanya, atau secara interaktif saling memberitahu kepingankepingan yang mana yang harus dimasukkan sesuai dengan lubang yang benar.

Sementara itu, pada indikator mengklasifikasikan fungsi anggota tubuh manusia berdasarkan kriteria alat indera dan bukan alat indera pemahaman anak muncul baik pada proses pelaksanaan permainan, maupun ketika dilakukan review oleh guru. Pada proses permainan, anak-anak setelah berhasil memasukkan kepingan bergambar anggota tubuh ke dalam kategori lubang yang benar, guru mengkonfirmasi jawaban tersebut kepada anak dengan memerintahkan anak menunjuk langsung anggota tubuh mereka sesuai dengan apa yang ada di gambar. Dengan demikian, selain memahami konten dari permainan, pemahaman anak juga diperkuat dengan mengobservasi langsung anggota tubuh mereka sendiri. Pada kegiatan review, guru menguatkan kembali dengan membimbing anak secara klasikal berkepinganusi dan bertanya jawab terkait indikator mengklasifikasikan fungsi anggota tubuh manusia berdasarkan kriteria alat indera dan bukan alat indera.

Pemahaman sains biologi yang teramati dan berkembang dalam penelitian ini terlihat karena adanya pemberian tindakan yang sangat bermanfaat bagi keberlangsungan pemahaman anak terhadap pembelajaran sains biologi . Permainan karambol dapat meningkatkan pemahaman anak terhadap pembelajaran sains biologi , permainan karambol menjadi efektif karena permainanya dikemas dalam bentuk permainan yang menarik, unik, dimana konten sains biologi yang semula hanya dapat dilihat dan dipelajari dari hanya penjelasan guru dan buku pelajaran di dalam kelas, akan tetapi melalui tindakan ini anak dapat menyaksikan dan mengambil peran secara langsung untuk memainkannya dalam sebuah permainan papan yang sudah sangat familiar di kalangan anak namun dikemas dengan tampilan yang sangat berbeda.

Mengacu pada pembahasan diatas, maka dapat disimpulkan bahwa pemahaman sains biologi anak dapat ditingkatkan melalui permainan karambol. Pemahaman sains biologi anak yang berkembang meliputi 24 indikator sebagaimana 
Peningkatan Pemahaman ...

Subhan

dipaparkan di atas dimana masing-masing memiliki tujuan dan merupakan suatu rangkaian yang menjelaskan bagaimana anak menguasai konten ciri-ciri morofologis hewan dan tumbuhan, lingkungan tempat hidup hewan dan tumbuhan, macam-macam anggota tubuh manusia serta fungsi anggota tubuh manusia yang mencerminkan pemahaman sains biologinya secara keseluruhan.

Peningkatan pemahaman sains biologi anak melalui permainan karambol juga terkait dengan disiplin ilmu lain. berikut dapat digambarkan pada bagan dibawah ini.

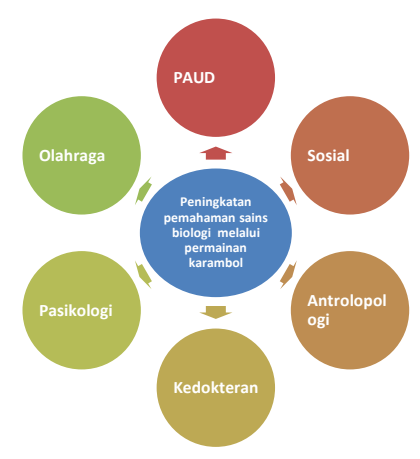

Gambar 4. Kajian Peningkatan Pemahaman Sains biologi Melalui Permainan Karambol Berdasarkan Beberapa Disiplin IImu Terkait

Berdasarkan perspektif psikologi, anak memainkan permainan karambol merupakan kegiatan yang menyenangkan dan sesuai dengan dunia anak. Permainan karambol merupakan permainan papan populer yang telah lama berkembang; dimainkan secara berkelompok dengan menuntut kompetisi diantara para pemainnya. Hal ini yang membuat anak merasa lebih tertantang dan menarik untuk dimainkan, apalagi dengan integrasi konten sains biologi pada semua komponen permainanya membuat guru lebih mudah menyampaikan materi ketika melaksanakan pembelajaran. Lev Semionovich Vygotsky menjelaskan, perkembangan intelektual termasuk pemahaman hanya dapat dipahami hanya berdasarkan konteks historis dan budaya yang dialami anakanak. Perkembangan pemahaman anak bergantung pada "sistem tanda" yang ada bersama masing-masing orang ketika mereka bertumbuh; simbol-simbol yang diciptakan budaya untuk membantu orang berfikir, berkomunikasi, dan memecahkan masalah. Hal ini sejalan dengan prinsip kompetisi antar anak ketika melaksanakan permainan karambol; dimana anak-anak berinteraksi, saling berkomunikasi memahami konten sains biologi untuk memenangkan permainan.

Pada permainan karambol guru selalu memberikan pengarahan sebelum anak melakukan permainan, dengan begitu anak melakukan permainan sesuai prosedur 
JURNAL PENDIDIKAN USIA DINI

Volume 10 Edisi 1, April 2016

dan peraturan yang telah ditetapkan. Untuk

pertemuan, kegiatan inti guru memenangkan permainan, anak harus mengkomunikasikan apa yang harus memahami dengan baik konten sains biologi yang terintegrasi delam permainan sehingga anak selalu memperhatikan, mencari tahu, dan konsentrasi, dan gigih dalam mencari tahu informasi tentang konten-konten tersebut baik dari temantemannya ketika bermain maupun dari guru ketika melakukan review di akhir kegiatan permainan.

Ditinjau dari Ilmu sosial adalah ilmu yang mencakup semua aspek didalam kehidupan mulai dari sifat seseorang atau individu, interaksi antar individu, antara individu dan kelompok, dan interaksi antara kelompok dan kelompok. Untuk mempermudah sebuah hubungan diperlukan komunikasi, komunikasi yang baik akan mempermudah seseorang dalam menerima atau menyampaikan pesan. Latif menyatakan komunikasi yang baik membantu anak untuk mengembangkan kepercayaan dirinya, harga dirinya dan hubungan-hubungan yang baik dengan orang lain. Permainan karambol merupakan kegiatan yang memerlukan komunikasi baik antara anak dengan anak ataupun anak dengan guru. Guru selalu mengkomunikasikan prosedur-prosedur kegiatan, dari kegiatan pembuka, kegiatan inti sampai dengan kegiatan penutup. Pada kegiatan inti guru mengkomunikasikan apa yang akan dilakukan pada kegiatan setiap dilakukan, dan pada kegiatan penutup guru mengkomunikasikan konten-konten sains biologi yang terkandung dalam permainan. Melalui komunikasi yang baik tersampaikan pesan dengan baik pula sehingga anak mudah dan mampu memahami konten sains biologi dengan benar.

Ditinjau dari ilmu antropologi; ilmu yang mempelajari tentang manusia. Manusia dituntut untuk belajar sepanjang hayat. Belajar bukan hanya berupa akademis saja, belajar dari pengalaman merupakan pembelajaran yang amat baik. Kita mampu mengetahui kesalahankesalahan yang telah kita lakukan pada hari kemarin sehingga untuk hari esok kita mampu bersikap hati-hati dan tidak melakukan kesalahan yang sama lagi. Seperti yang dikatakan Vygotsky bagian dari warisan biologis baik itu pada hewan maupun manusia adalah proses yang disebut sinyalisasi (sugnalization), proses ini adalah pengenalan stimuli yang terjadi disebuah lingkungan. Seperti pada anak kecil meletakkan tangannya diatas kompor menyala dan merasakan sakit, saat mendekat kompor lagi dia akan ingat rasa sakit dan bertindak hati-hati. Demikian dengan permainan karambol, anak belajar dari pengalaman setiap pertemuan demi pertemuan, anak akan mendapatkan pengalaman dan berlajar mengenai konten 
Peningkatan Pemahaman ...

Subhan

sains biologi yang terintegrasi pada setiap komponen permainan. Anak belajar bagaimana memenangkan permainan dengan memahami konten-konten sains biologi yang ada pada permainan tersebut, sehingga pertemuan demi pertemuan yang dilaluinya ia lebih matang dalam mempersiapkan pemahamannya terhadap konten tersebut dan belajar bagaimana ia dapat mahir secara teknis agar kepingankepingan dapat masuk ke dalam lubang yang sesuai secara benar. Hal ini juga tidak luput dari bimbingan dan motoivasi dari guru agar anak dapat menyelesaikan permainan dengan baik dan timnya keluar sebagai pemenang.

Ditinjau dari ilmu PAUD yang merupakan suatu upaya pembinaan yang ditujukan kepada anak sejak lahir sampai dengan usia enam tahun yang dilakukan melalui pemberian rangsangan pendidikan untuk membantu pertumbuhan dan perkembangan jasmani dan rohani agar anak memiliki kesiapan dalam memasuki pendidikan lebih lanjut. Anak merupakan anugrah yang diberikan oleh sang maha pencipta, sejak didalam kandungan pun anak sudah menunjukkan perkembangan yang mampu dirasakan sang ibu, oleh karena itu seorang ibu harus selalu menstimulus anak sejak dari dalam kandungan. Pada anak usia dininya mendapat rangsangan yang cukup dalam pengembangan kedua belah otak kanan maupun otak kirinya akan memperoleh kesiapan yang menyeluruh dalam menerima pembelajaran. Belajar seraya bermain merupakan kegiatan yang efektif untuk mengembangkan kecerdasan anak karena anak lebih dalam kondisi yang menyenangkan.

Ditinjau dari ilmu kedokteran fisiologis, merupakan cabang ilmu kesehatan yang mengkaji tentang fungsi tubuh yaitu bagaimana cara kerja tubuh dalam mengendalikan dan memposisikan semua fungsi organ agar berada sistem dan jalur yang semestinya. Ilmu kedokteran fisiologis dan sains biologi sama-sama mengkaji tentang fisiologis mausia, namun sains biologi lebih megarah pada bagaimana meletakkan dan mengenalkan sains dasar kepada anak agar anak memiliki pemahaman dan pengatahuan tentang dirinya sendiri. Ketika anak bermain karambol dengan tema jenis dan fungsi anggota tubuh manusia, sesungguhnya anak telah mulai mempelajari dasar-dasar ilmu kedokteran; kedokteran fisiologis yang banyak berbicara tentang sistem dan fugsi organ manusia. Anak melalui permainan karambol banyak mengenali dan memahami bagaimana fungsi dan bentuk organnya secara sederahana. Melalui pengenalan ini, anak akan lebih menghargai dirinya, berlatih untuk tetap menjaga kebugaran dan kesehatan sejak usia dini.

Ditinjau dari ilmu olahraga, permainan karambol merupakan cabang olahraga yang masuk dalam daftar permainan papan. Permainan papan sebagai salah satu cabang keolahragaan merupakan 
permainan yang dapat melatih ketangkasan organ pergerakan seperti tangan dan kaki. Ketika anak bermain karambol, anak sesungguhnya telah melibatkan banyak koordinasii motorik yang melibatkan mata, tangan, lengan, dan juga kaki. Dengan bermain karambol, anak mengetahui dasardasar ilmu keolahragaan yaitu memaksimalkan pergerakan organ untuk menjaga kebugaran dan kesehatan.

Frank dan Teresa Caplan menjelaskan bermain membantu pertumbuhan dan perkembangan anak, bermain merupakan kegiatan yang dilakukan secara sukarela, memberi kebebasan anak untuk bertindak, memberikan dunia khayal yang dapat dikuasai, mempunyai unsur petualang di dalamnya, meletakkan dasar pengembangan bahasa, mempunyai pengaruh yang unik dalam pembentukan hubungan antar pribadi, memberi kesempatan untuk menguasai diri secara fisik, memperluas minat dan pemusatan perhatian, cara anak menyeldiki sesuatu, cara anak mempelajari peran orang dewasa, cara dinamis untuk belajar, menjernihkan pertimbangan anak, dan merupakan kekuatan hidup.

Dampak permainan karambol dapat diamati dari proses pembelajaran seharihari di sekolah dan kegiatan anak selama di rumah. Anak dalam kesehariannya di sekolah lebih memahami tentang dunia hewan dan binatang serta diri anak sendiri. Dalam pembelajaran anak dapat memahami materi berbagai hewan dan tumbuhan baik secara fisik maupun tempat hidup hewan dan tumbuhan tersebut. Anak juga lebih memamahamii keadaan fisik dirinya sendiri dan mengetahui bagaimana fungsi dan manfaat dari masing-masing anggota tubuhnya sendiri. Aspek-aspek dalam permainan karambol menyisipkan pesanpesan pembelajaran sains biologi cukup berperan penting dalam keberlangsungan pemahaman anak. Guru selalu membimbing dan mengajak anak untuk selalu mengapikasikannya dalam kehidupan sehari-hari.

Pemahaman sains biologi merupakan bekal yang harus dimiliki setiap anak sebagai generasi penerus bangsa yang memiliki pengetahuan dan pemahaman yang baik terhadap diri sendiri dan lingkungan. Dengan lebih memahami kondisi diri sendiri dan juga keadaan alam sekitar membuat anak lebih peka dan peduli terhadap eksistensi penciptaan dirinya dan lingkungan oleh Yang Maha Kuasa. Karena pada jenjang kehidupan dan pendidikan yang lebih tinggi, anak akan menghadapi tantangan lingkungan dan pembelajaran sains biologi yang lebih kompeks. Dengan bekal pemahaman sains biologi anak mampu mengatasi tantangan-tantangan tersebut dan lebih berpeluang dapat menyelesaikan setiap permasalahan yang mereka temui.

Permainan karambol menjadi media yang efektif dalam menanamkan pemahaman sains biologi pada anak, karena permainan karambol dikemas dengan mengintegrasikan konten sains biologi yang selama ini hanya dapat pahami dari buku 
Peningkatan Pemahaman ...

Subhan

bacaan dan penjelasan guru kemudia disajikan secara lebih menarik melalui permainan karambol. Permainan karambol merupakan permainan yang dilakukan secara tim dengan menuntut kompetisi diantara para pemainnya. Hal ini menjadi tantangan tersendiri bagi anak untuk memamahi konten sains biologi yang terintegrasi dalam permainan tersebut agar dapat memenangkan permainan.

\section{Simpulan}

Peningkatan pemahaman sains biologi melalui permainan karambol dapat ditentukan dengan melihat kenaikan ratarata TCP anak. Berdasarkan hasil pengamatan tindakan yang telah dilakukan terhadap 22 responden pada siklus I, dapat diketahui bahwa pemahaman sains biologi anak mengalami peningkatan TCP sebesar 10,63, pada pra-intervensi diperoleh ratarata TCP kelas sebesar 22,23 sehingga TCP pada siklus I sebesar 63,82. Pada siklus II pemahaman sains biologi anak mengalami peningkatan TCP sebesar 16,91 dimana siklus II anak memperoleh rata-rata TCP 80,73. Maka pada akhir siklus II penelitian dikatakan berhasil karena presentase kenaikan lebih dari kriteria keberhasilan yang disepakati oleh peneliti dan kolabolator.

Meningkatnya pemahaman sains biologi anak diakibatkan karena permainan karambol merupakan permainan yang menyenangkan dan dapat membuat anak tertantang. Konten sains biologi disajikan pada semua komponen permainan karambol secara menarik dan dikemas menantang melalui kompetisi antar tim. Disamping itu, dalam proses permainannya, anak dalam satu tim harus membangun komunikasi yang baik karena mereka memerlukan kerjasama tim untuk berbagi saran, arahan, dan juga strategi menyentil kepingan yang baik antar teman satu timnya. Permainan karambol dapat memicu anak untuk memiliki pemahaman yang baik mengenai ciri-ciri morfologis hewan dan tumbuhan, lingkungan tempat tinggal hewan dan tumbuhan, macam-macam anggota tubuh manusia dan fungsi anggota tubuh manusia. Permainan karambol menjadi efektif karena pada umumnya lebih berkesan, dimana dikemas dengan terintegrasi konten sains biologi dimana sebelumnya anak hanya mengetahui konten-konten tersebut hanya dari buku pelajaran dan penjelasan guru di dalam kelas. Dengan demikian, menjadi tantangan tersendiri bagi anak ketika ia sudah sangat familiar dengan suatu permainan tiba-tiba permainan tersebut digunakan guru untuk membelajarkan sains biologi kepada anak sehingga melibatkan partisipasi aktifnya secara penuh. Dalam proses permainan, anak harus memamahi dengan baik konten-konten sains biologi yang terintegrasi agar dapat memenangkan permainan dari anak lainnya. Kemampuan ini terlihat saat penelitian berlangsung saat dilaksanakannya permainan karambol.

\section{Rekomendasi}

Berdasarkan kesimpulan yang telah dikemukakan, maka peneliti mencoba untuk memberikan saran-saran sebagai berikut. 1)Guru, permainan karambol dapat dilakukan di sekolah sebagai variasi kegiatan pembelajaran sains biologi yang 
menarik dan menyenangkan bagi anak. Guru sebaiknya membimbing, memberi pengarahan, sekaligus memberikan kesempatan kepada anak untuk berdiskusi dan bertukar pikiran terkait bagaimana cara memahami konten sains biologi agar dapat menyelesaikan dan memenangkan permainan. 2) Orang Tua, orang tua diharapkan dapat memberikan stimulasi yang sama sebagai bentuk kelanjutan program kegiatan bermain yang dilakukan guru disekolah. Dengan adanya kerjasama antara pihak sekolah dan orang tua diharapkan pemahaman sains biologi anak akan berkembang dengan optimal. 3) Peneliti Lain, bagi peneliti lain diharapkan memperkaya kajian-kajian penelitian terkait peningkatan pemahaman sains biologi anak dengan menemukan berbagai kegiatan bermain ataupun media yang tepat dan sesuai dengan perkembangan anak usia dini baik yang dilakukan di TK meupun tingkat SD awal.

\section{Daftar Pustaka}

Acramento, Preschool Learning

Foundation; History Social Science and Science, California: CDE Press, 2012.

Chalufour and Karen Worth, Science in Kindergarten A reading from the $C D$ accompanying Developmentally Appropriate Practice in Early Childhood Programs Serving Children from Birth through Age 8, Third Edition, USA: NAYC, 2006.

.Ludington, Carrom Game Board Official Rule Book, http://www.carrom.com, diakses 9 Nopember 2015.
Moeslichatoen, Metode Pengajaran di Taman Kanak-Kanak, Jakarta: Rineka Cipta, 2004.

Nugraha, Ali. Pengembangan Pembelajaran Sains pada Anak Usia

Dini Jakarta: Departemen Pendidikan Nasional, 2005.

Nurani, Yuliani. Buku Kerja Guru Implementasi Kurikulum 2013

Pendidikan Anak Usia Dini, Jakarta: Yayasan YEBEFO, 2015.

Rossalind Charlesworth dan Karen K. Lind, Math And Science For Young Children, New York: Delmar Publisher Inc., 1990.

Slavin, E Robert. Psikologi Pendidikan Teori dan Praktik Edisi Kesembilan, Jakarta: Indeks, 2011.

Worth, Keren dan Sharon Grollman. Worm Shadows and WhirlpoolsScience in The Early Childhood Education. EDC Newton. Washington, 2003.

Yuliani Nurani, Konsep Dasar Pendidikan Anak Usia Dini, Jakarta: Indeks: 2009. 